\title{
The Value added of Education at a Public Research University
}

\author{
April C. Mason, Ph.D., Provost and Senior Vice President \\ Kansas State University
}

7 he Carnegie classification system for universities is important. Kansas State University is a very high research public university. At conferences, adminis-

1 trators divide around this categorization. Ranking of these universities is monitored by growth in research dollars. Faculty are nominated for national awards by this category. Universities invest in startup packages to assist faculty with their research success, and success is monitored against metrics in strategic plans with research, creative activity, scholarship and discovery.

Universities also highly value student success. This factor is not added as an afterthought-faculty and staff at public research universities work to help students succeed. The intentional advising, technology to assist advisors, early warning programs, tutoring, learning communities, first year seminars - and many other programs, all are set up to assist students to be successful.

Recently, the Kansas legislature passed a law that Kansas public universities must make available the cost of education, the time to degree, and the salary a graduate can expect upon completion. The website development project was not without controversy, academic leaders were wary but the idea is sound if executed well. Students should know what they will invest and what type of return they can expect.

Each public research institution identifies peers against which they measure the progress on benchmarks of their strategic plans, all public research universi ties. Student enrollment professionals also identify a set of institutions, compet- itive peers where students decide to attend for their education. These may not be anything like a public research university.

What factors lead to competitive schools for attendance? A few include cost, value of education, undergraduate research opportunities, scholarships, advising and time to degree completion. There are many others.

What does a public research institution provide in the value added of education that a non-research university does not or cannot? Public research universities can be expensive when compared to other means of education. Although the data is flawed in many cases, the new Kansas legislatively mandated website, does not show a happy picture for the return on investment of a degree from the research publics in the state compared to the comprehensive lower research universities.

Do students know research is being conducted at public research universities? Is the percent of students growing that participate in undergraduate re- 
search? Do faculty bring their own research into the classroom to help inform? Do students see a difference? Even small private liberal arts college provide some level of undergraduate research. Do the faculty and staff of large public research powerhouses get students excited about research? Do they do this for a majority of their students?

This fall at the APLU meetings in Austin, Texas, this topic of value added of public research university education is going to a big topic. Large public research universities will not compete with the regional universities on price and continue to survive. The large public universities will need to compete with the regionals on value added. Value added is not the same as quality. Personally being a product of the small liberal arts college, I do not wish to impugn the quality of education at other institutions in Kansas and elsewhere, but it is critical to show the value added of the public research education. From the very beginning of a student's career, actually from the very first time a potential student reads material about the public research university, visits the campus, the value added of being a research intensive institution must be clear and evident.

It is critical the research superstars at a university are also in the classrooms, being teaching superstars. A great deal is asked of faculty. The alternative choices of education for today's students are so many. Mike Leavitt of Western Governors University describes WGU having over 70,000 graduates and 60,000 current students. The average time to degree is 2.5 years at a cost of $\$ 6,000$. WGU monitors a $\$ 10,000$ increase in salary for graduates. Public research universities cannot compete with that, nor do they want to. But there will be students who need/want/have to have a WGU degree. What can be done to make the educational value of a degree from the public research universities mean more, value more, help more, and better prepare students?

My own two stepchildren attended Purdue University while I was a faculty member there. I am proud of the fact that one Christmas, Jeff wanted to get my father the book his history faculty member has just published on the Civil War. That faculty member told his class about his book - and that day Jeff was listening! Cleaning out my parents' home years later after they were gone, I came across the book, inscribed by the professor, because Jeff had asked him. Scholarship of the faculty member, shared in the classroom that touched a student. This is one of many stories that can be told.

Recently at a foundation trustees meeting at Kansas State University, a panel of students were asked to talk about their experiences at the University. A trustee, a local banker asked this question to the panel: if I gave you $\$ 10$ million dollars today what would you suggest be done with it for the university? The answers were truly amazing. One student indicated they would remodel the chemistry laboratories for research, another said they would increase stipends for graduate students, a third indicated they would help more students go on study abroad experiences.

Why do administrators stay in higher education administration? It is hard, the states continue to divest, there are more and more expectations, less money, and 
the future does not look bright. However, the future does not look bright, if higher education stays the same. Higher education will have to be different. Administrators will have to clearly articulate what public research universities are and what they are not. Public research universities may have to be smaller, they may have to be substantially different, but they must show the value of what they are, why an education from a public research university is important and why the average undergraduate, state legislator, governor or parent should care.

Standing still is not an option. Being great at certain things and focusing on those things is essential. Strategic thinking, planning and action are more important than at any other time in the history of public research university education. 